\title{
REPRESENTING SOMALI RESETTLEMENT IN ITALY: THE WRITING OF UBAX CRISTINA ALI FARAH AND IGIABA SCEGO
}

\section{VIVIAN GERRAND}

\begin{abstract}
Sommario
In Italia durante gli ultimi cinque anni diversi scrittori italosomali hanno pubblicato le loro opere. Molti di questi testi complicano le nozioni prevalenti dell'identità italiana e la chiusura nei confronti dell'immigrazione in Italia, evidenti nella questione della cittadinanza. Con la prospettiva di aumentare la conoscenza delle condizioni precarie dei rifugiati somali in Italia e di destabilizzare l'idea di un'identità italiana singolare e culturalmente omogenea, questo articolo prende in considerazione la scrittura di Ubax Cristina Ali Farah e Igiaba Scego, che appartengono alla nuova generazione di 'scrittori migranti' in Italia. Insieme alle opere di altri scrittori migranti che vivono in Italia, la produzione letteraria di queste autrici apre spazi in cui i lettori possono riflettere sulla dinamica interattiva fra culture, storie e lingue piuttosto che vedere queste entità in modo fisso ed esclusivo.
\end{abstract}

After the war Somali men and women scattered themselves all over Europe and the world, and I collected all the memories that I could bring to mind, especially memories of telephone conversations with the dearest and closest people because, even though we don't see each other anymore, some sort of web of relations remains which functions telephonically. It's wonderful because these relationships are kept alive via anecdotes, things that seem trivial... since it's very difficult to re-instigate a dialogue with a person you haven't had contact with for a long time. Yet these small things make it easier because the everyday is something that belongs to everyone. This is associated with the diaspora; in a sense also to remember that Somalia is historically linked to Italy even though this is hardly ever brought up.

Cristina Ali Farah, www.sagarana.net/scuola/seminario5/seminario1.html 
Identity is a big issue... I feel like I am everything, but sometimes I feel as though I am nothing. When I'm on the bus, for instance, and I hear the phrase: 'These foreigners are the ruin of Italy', I feel all eyes on me...or when a Somali woman (usually a distant relative) notices that my wee makes more noise than hers... I leave the bathroom unaware that my wee has been spied on... I receive the poisonous comment: 'You're nijas ', you've still got the kintir' ${ }^{2}$.You'll never find a husband'. ${ }^{3}$

Igiaba Scego, 2006 Salsicce. In Pecore Nere. 30

The growing body of contemporary Italo-Somali literature in Italy, largely published in Italian, challenges pre-conceived nationalist notions of Italian identity in several ways. This article explores six key texts by two Italo-Somali authors, Ubax Cristina Ali Farah and Igiaba Scego, who have received critical acclaim and public recognition for their writing. Ali Farah's novel Madre Piccola represents Somalis living in the diaspora, suggesting alternative ways of belonging. Her racconti brevi: Rapdipunt and L'Italia e $i$ somali dimenticati remind readers, respectively, of Italy's colonial ties with Somalia and the plight of Somalis attempting to resettle in Italy. Scego, in her novel Rhoda, and short stories Dismatria and Salsicce, focuses on the conflicts and tensions experienced by Somalis living in Italy; her characters alternate between feelings of alienation and being at home in their host society.

Paul Gilroy and Sandro Mezzadra argue that the idea of diaspora destabilizes fixed notions of belonging inherent in much nationalist thinking. For Gilroy, "diaspora is a useful means to reassess the idea of essential and absolute identity [...] because it is incompatible with that type of nationalist and raciological thinking" (Gilroy, 2000:125).

\footnotetext{
1 Impure.

2 Clitoris.

3 All translations from Italian into English that appear in this article are the author's own.
} 
Sandro Mezzadra (2006:79) suggests that new "transnational social spaces, diasporas, movements of cultural hybridity and identity" are capable of challenging fixed views of belonging. Nikos Papastergiadis (1998:xi) proposes that we see diaspora in terms of "cultural transformation' insofar as 'for a diasporic sensibility', the 'homeland is $[\ldots]$ both absent and present."

Italo-Somali writing in Italy can be viewed as a source from which to glean insight into the ways in which Italian national identity has been imagined. Alessandro Portelli investigates innovative ways in which Somali writing, as part of a wider corpus referred to as 'migrant literature', is influencing Italian. He suggests that Italian is becoming a 'multicultural' and 'postcolonial' literary language. After many years of scant attention towards migrant writing, there now exists a body of scholarship concerned with writing accruing around the migrant presence in Italy. Portelli acknowledges, however, that such scholarship rarely figures under the banner of 'Italian literature' or 'multicultural literature' but, rather, is still referred to as 'comparative', "as though it were still foreign to the Italian cultural environment and literary experience" (Portelli, 2006:474).

To begin to comprehend the ways in which Italian identity is called into question in and by the writing of Cristina Ali Farah and Igiaba Scego, it is necessary to first acknowledge the cultural and historic links between Italy and Somalia. The fact that the Horn of Africa was known as ' $L$ 'Africa Orientale Italiana' suggests the extent to which the Italian presence was formative for the countries in the region. Somali experiences are particularly relevant when reflecting on Italian identity insofar as they are "the product of a relationship established under colonial rule". In many senses, the literature of the Somali diaspora can help develop "critical insight into Italy's recent colonial past and its role in contemporary Italian culture", allowing us to revisit "repressed memories" (Ahad \& Gerrand 2004:19).

Italian colonial administration of Somalia from the partition of Africa in the 1880s until Somalia's independence in 1945 has been regarded as brief and benevolent in comparison with, for example, 
French and British colonialism. Indeed, alongside the notion of a 'weak colonialism', the Italiani, brava gente myth has been central to constructions of Italian identity (Del Boca 2005). Colonial studies were until recently limited to the work of historians such as Angelo Del Boca. Fabrizio De Nonno and Neelam Srivastava (2006:371) attribute this fact to "the impossibility of access to official colonial records for several decades" post 1945, and to "the general refusal of the Italian governing class to engage in a sustained and public debate about colonialism, as had occurred in other European ex-colonial nations".

Consequently, Italy's colonial legacy has only recently begun to be integrated into "larger narratives of Italian national experience" (BenGhiat \& Fuller 2005:1). Italian postcoloniality is an understudied area, according to De Nonno and Srivastava. (2006:371) Alessandro Triulzi is concerned with what he terms the "ambiguous displacements" of colonial memory within both Italian society and Italy's ex-colonies. Likening "colonial memory and its renewed positioning" to "back-up files which can be accessed according to convenience", he argues that the "the legend of Italian colonialism as different, more tolerant, and more humane than other colonialisms remains obstinately at large" in spite of the re-emergence of Italian colonialism "as a topic of heated debate" (Triulzi 2006:430).

Italian responses to the influx of Somali migrants and refugees following the outbreak of civil war in Somalia in 1991 have been shaped by narrow definitions of what it is to be Italian. Somali refugees in Italy, for instance, are rarely granted Italian citizenship, in spite of the fact that their heritage was shaped significantly by the Italian presence in Somalia over decades. Legislation 91 passed in 1992 specifies that children born in Italy to foreign parents are not eligible to become Italian citizens until they turn 18, at which time they must prove that they have resided in Italy without interruption, and have a year in which to claim citizenship (Giustiniani 2003:152).

Christina Siggers Manson observes that the conditions for Italian citizenship acquisition deny "the possibility of a coexistence of 
cultures, isolating Italy from the world around it" (Siggers Manson 2004:84). Based upon jus sanguinis, where citizenship is determined by blood ties rather than place of birth (jus soli) (Einaudi 2007:186), citizenship is denied to bodies that lie outside of Italian bloodlines.

Alessandro Triulzi considers the dilemma facing what he terms 'disenfranchised ex-colonial subjects': "In postcolonial Italy, the African 'alterity' is dealt with, culturally and socially, through the ambiguous return of colonial clichés together with representations of modernity and citizenship which, while including sanitized narratives of the country's colonial past, exclude African migrants from full participation in cultural, social or political life" (Triulzi 2006:430-32). Indeed, as Somali writer Nuruddin Farah notes:

The majority of Somalis do not qualify for refugee status, according to the Italian authorities close reading of the 1951 Geneva Convention and Protocol, because they have no tangible evidence that, as individuals, they are fleeing persecution in their land. Hence the provisional admission to the country as 'visitors' [...] Italians argue that Somalis have come to Italy for years, long before the recent influx of Senegalese and other Africans from North and Central Africa, and there is definitely no need to alter their status at the exorbitant expense of a redefinition. (Farah 2000:63)

Italo-Somali writers in Italy, writing in Italian, can bring the commonly covert Italian colonial legacy back into focus so that it may enter the "shared memory of the nation" (Pugliese 2007:11). Perhaps most crucially, particularly from the perspective of Somalis residing in Italy, Italo-Somali writing draws attention to the colonial and historical ties between Italy and Somalia. In this way such writing can engender insight into how these ties might be maintained or reviewed with a greater degree of reciprocity and responsibility than is presently occurring, perhaps in the form of citizenship rights for displaced Somalis. 
Lidia Curti considers "authors belonging to the Somalian diaspora in Italy [...] [to] have added their voice to [Nuruddin] Farah's considerations on the proximity between the two countries" (Curti 2007:63). Ali Mumin Ahad maintains that writers from the diaspora can "create reminiscences of a forgotten past, enact creative cultural contamination with the remnants of memories of that "place in the sun', which has had an important role in Italian $20^{\text {th }}$ century history" (Ahad 2006:241-42). Sandra Ponzanesi argues accordingly that "the emerging Italian female literature on immigration from the Horn of Africa [...] allows for an exploration of the key issues of postcolonialism with all of its contradictions and paradoxes, and for the resuscitation of an obscure chapter in Italian history which is that of colonialism" (Ponzanesi 2004:26).

Italian born Ubax Cristina Ali Farah and Igiaba Scego, for example, are well-placed to begin this exploration. Ali Farah was born in Verona in 1973 to an Italian mother and a Somali father who was working as a stockbroker in Italy when he encountered Ali Farah's mother who was studying at the time. Her father returned to Somalia when she was an infant and when their daughter was three, her mother took Ali Farah to Mogadishu where she remained until she was 18 when she was forced to flee in 1991 due to the civil war. Ali Farah and her mother went to live in Pecs, Hungary, before returning to Verona. She has been living in Rome for the past ten years. Igiaba Scego was born in Rome in 1974 to parents who were in exile having escaped from Somalia following Siad Barre's coup (Gnisci 2005:102). The fact that Ali Farah and Scego were raised bilingually and have lived most of their lives in Italy, yet are customarily positioned as 'migrant writers' is worth consideration. Indeed, Ali Farah admits:

The fact, for instance, that I'm Italosomali: most of the time people forget it. It's not something I must always affirm but it's important because when someone says: "you're from that other culture", it's as though they'd prefer to recognize your alterity over what you have in 
common with them. (Interview with Cristina Ali Farah by Vivian Gerrand, Rome, 22/7/05)

At the Sagarana seminar for migrant writers held in Lucca, Italy, in 2005 , there was a sense in which authors of non-Italian background labeled 'migrant writers' have become trapped and stuck in a ghetto (www.sagarana.net). Ali Farah reminds us of the privilege of the recognition such a label entails insofar as a marginal status affords them distinction from the mainstream. She sees her positioning within this genre as advantageous in that such recognition, garnered via strategically essentializing her perceived otherness, has enabled her to publish her writing. Igiaba Scego, conversely, has declared that she is ready to distance herself from the term 'migrant writer' so that she might be seen as a writer in her own right (Capitani \& Coen 2005:43).

Whatever the relationship with the category 'migrant writing', the authors in question may use their hybridity to interrogate Italo-Somali relations and negotiate between them in powerful ways. Jacqueline Lo $(2005: 153)$ writes that the term "'hybridity' [...] holds the potential to unsettle and dismantle hegemonic relations because it focuses on the process of contestation between cultures".

In this way, hybridity can be viewed as intentional, as 'a form of political intervention' rather than being perceived as a natural outcome of cultural mixing. Monica Hanna contends that the 'multiple consciousness' of 'African-Italian writers like Igiaba Scego' is capable of "interrogat[ing] and [...] challeng[ing] the established discourses of difference-based identity politics". This is the case to the extent that the texts produced by these writers offer "alternative concepts of identity that incorporate multiple affiliations" (Hanna 2004:67).

Nikos Papastergiadis (1998:182) warns against viewing "minority discourse as a category which contains a unified body of writing" insofar as such perceptions risk "jeopardising the chief characteristic of this field, that is, cultural difference". Bearing this caveat in mind, we might compare the ways in which the two Italo-Somali writers 
work to unravel aspects of Italian identity. One readily identifiable aspect that distinguishes the two writers from first generation 'migrant writers', for instance, is that they are native Italian speakers. They are thus able to use the language more freely than first generation writers, who Portelli claims "tend to [...] sound at times as if they write with the handbrake on" (Portelli 2006:479).

More specifically, one can observe differences between the authorial concerns in their writing. Igiaba Scego's texts tend to be situated in Italy and directly take issue with the politics of citizenship, cultural identity and multiculturalism. The writing of Cristina Ali Farah, on the other hand, recuperates more poetically the experiences and points of view of Somalis living in the diaspora, via everyday interactions such as telephone conversations with relatives living in myriad countries.

In an interview I conducted with Ali Farah in 2005, she spoke of how, akin to many of her Somali relatives abroad, the father of her firstborn would call her from Canada, where he lives, and recount seemingly trivial anecdotes which she began to record and incorporate into her writing:

Because the father of my son lived in Canada for many years he would call me a lot...He needed to speak to me, to feel close again, so he would recount anecdotes; absurd things like that, even after so many years. And he wasn't the only one to do so. Many people would do it: relatives, neighbours, cousins. They would tell me all these things, these anecdotes and sometimes the phone calls would last for over an hour...and it became hard work after a while because it was heavy-going. So I decided to write down what they said to me. (Interview with Ubax Cristina Ali Farah by Vivian Gerrand, 2005)

Ali Farah's first novel, Madre Piccola, published by Frassinelli in 2007 , is evidently inspired by the notes taken during aforementioned telephone conversations. 
Meet you? I wish. To see my son again, return to that country where my love is destined. But how?

You have one minute.

Oh no, did you hear the voice? Time's up. Only a minute left. Come on, call me back, call me back. We've still got so much to say......

(Ali Farah, Madre Piccola, 2007:96)

The title of the book is a translation of the Somali word habar-yar which means little mother or (younger) maternal aunt. Ali Mumin Ahad contrasts this confidant figure with the more severe habar-weyn (big mother) who, being older than the child's mother, often participated in her care in infancy (Ahad 2006:268).

Madre Piccola has received wide acclaim. Many of the texts produced by migrant writers in Italy have been published by smaller alternative publishing houses whose published material seldom makes it on to the shelves of mainstream bookstores. Madre Piccola, conversely, is accessible to a wider audience and is thus capable of generating broader awareness of the plight of Somalis. A non-linear narrative, the novel is recounted in a series of deferments, flash-backs and revivals from multiple perspectives. Each of the chapters is entitled with the name of one of the cast of three protagonists (two women and one man) - Domenica Axad, Barni, and Taageere: the perspectives of these characters frame the narrative of intersecting experiences of dislocation and attempted resettlement in Italy.

The scattered realities of the Somali diaspora in Madre Piccola are articulated via memory, telephonically, and in an epistolary form towards the end by the Italosomali character Domenica Axad. For example, Domenica remembers her cousin Libeen who alludes to the importance of orality in Somali culture: "Memories mixed with recognition...forgotten Somali. Every day I would write notes in my journal, verbs to be memorized. Western way, Libeen would say. According to him, you only learn from what is said out loud" (MP 
102-03). One of the chapters called 'Taageere' is a telephone conversation between Taageere and his ex-wife who lives in Rome.

Halow? Shukri? It's Taageere, your ex-husband.

You don't recognize my voice it seems. I don't call? Of course I don't call. Every time you start like that. You don't call, you don't call. At the end of the phone conversation all you've said is you don't call. A whole phone card wasted to tell me that I don't call. No, stay cool. Today I'm at the call center. It's like I said. The owner is Somali and there are 5 booths. They do a cheap price on calls to Somalia. (57)

The telephone might be contemplated as a regrounding device that performs links between Somalis in the diaspora, wherever in the world they might be located. The "rift between [...] locations of residence and [...] locations of belonging" (Gilroy 2000:124) is temporarily closed during a telephone conversation. In this way, home is recreated each time a phone call is made to a far away relative. Technologies such as the telephone might be viewed as an "ex-centric communicative circuitry that has enabled dispersed populations to converse, interact, and [...] to synchronize significant elements of their social and cultural lives". The resulting possibilities may lead to transformation of the "concept of space itself" (129). This type of transformation might call into question rooted conceptions of belonging that are bounded to and determined by particular territories. Paul Gilroy, for example, sees the notion of diaspora as "an alternative to the metaphysics of 'race', nation, and bounded culture coded into the body" in that the concept contests "the cultural and historical mechanics of belonging" (123).

The linguistic code-switching that occurs throughout Madre Piccola can also be seen to reconfigure notions of rooted belonging insofar as the Somali words deployed deterritorialize the Italian language. Deleuze and Guattari regard "the deterritorialization of 
language as political action, for language itself is shaped by structures of power, and a minor use of language $[. .$.$] necessarily engages power$ relations as it encounters the restrictive controls of standard usage and sets nonstandard variables at play within the language" (Bogue 2003:100). Such variables can be noted below:

Qamar's shop: I can leave you the address if you're interested. He sells everything a Somali woman could want. Flamboyant Shaash ${ }^{4}$, garbasaar ${ }^{5}$ covered in floral veils, diric Jibuuti ${ }^{6}$, satin petticoats with embroidered pearls, long goonooyin ${ }^{7}$, guntiino ${ }^{8}$ made of hand-stitched raw cloth that everyone looked down their nose at once upon a time but today - since rare objects have become valuable - they are in fashion again. $(M P, 29-30)$

At the call centre they do cheap prices like what you pay for phone cards, but lots of people come by and they talk to you as though you aren't already on the phone: haye ${ }^{9}$ Taageere, how are you?, ah you're talking to your wife, say hi from me; haye sister, everything ok? The kid's grown, mashallah ${ }^{10}$, how old eh? (59-60)

The novel has an extensive glossary of Somali terms, some of which derive from Italian. The Somali word for 'cappuccino', for instance, is

\footnotetext{
4 Silk scarves with which married women cover their heads.

5 Light shawls with which women cover their head and shoulders.

6 Large women's dresses made from fine cloth with big sleeves.

7 Skirts (Goonooyin derives from the Italian word 'gonne').

8 Long embroidered women's wrap-around dresses.

9 Yes, okay. Used as a form of greeting.

10 Thank God.
} 
kabushiini (271). These words, in addition to the competence with which the characters in Madre Piccola speak Italian, draw attention to the cultural influences that are a legacy of Italy's colonial presence in Somalia. At the outset of the novel, when Barni speaks to a journalist in Rome who compliments her for "[her] Italian", she responds that she has "known this language since infancy", having "started learning it in the compulsory schools with [her] cousin Axad". Barni suggests that the journalist should know that "we Somalis almost always know how to speak Italian" (14).

The absence of any singular omniscient narrator in Madre Piccola, allows for insight into the collective lived experiences of the Somali community in Italy and many of the difficulties they have encountered. Moreover, the adoption of multiple voices makes readers aware of different trajectories and the ways in which these are constitutive of plural identities. One is reminded of Igiaba Scego's novel Rhoda, first published by the intercultural publishing house Sinnos Editrice in Rome in 2004, which is also narrated with an aberrant chronology, a structure that allows for the articulation of experiences of "epochal shifts" (Papastergiadis 1998:182-83), from the perspective of five characters: Aisha, Pino, Rhoda, Barni and Faduma. Each of these characters lives in Italy and their experiences of life there differ significantly: yet they are united by their attempts to comprehend Rhoda's self-annihilation.

Rhoda longs to return to Somalia and never feels welcomed by her host country: much is made of her refusal of gaal (a pejorative term denoting European 'unfaithful') culture and her investment in 'Negritude'. Her younger sister, Aisha, conversely, makes a consistent effort to interact with the dominant culture and remains optimistic she feels 'integrated' and at home in her beloved Rome to the extent that "she even likes the traffic" (Scego, Rhoda 2004:73). Barni and Faduma, Aisha and Rhoda's aunts, feel trapped in their roles as cleaners working for senile elderly Italian women.

Scego's novel opens with the voice of Aisha: one senses that it is privileged over that of her elder sister whose plight is marred by her 
chronic nostalgia for life in Somalia. Plagued by memories of life in Mogadishu prior to the civil war, time no longer has any meaning for Rhoda who is on a path to self-destruction from the moment she sets foot on Italian soil. She both dislikes and envies Italian popular culture in most of its forms. A dislike of "spaghetti, people kissing on the street $[\ldots]$ the lascivious gazes of men, the rudeness of bus drivers, isolated elderly people, young drug abusers and topless women" is undermined by her admission that "underneath, I would have liked to be like them" (74).

While working as a prostitute on a freeway in Naples, Rhoda meets Pino, a local who works as a volunteer to support street workers. Pino quickly becomes infatuated with the image of Rhoda, whose caricatured description: "Round head, big eyes, long legs, black skin, full lips, big breasts, generous hips" evokes sexualized colonial stereotypes of African women. She appears to Pino to be "the most enchanting creature he ha[s] ever seen" (18).

Rhoda contracts HIV and later returns to Mogadishu. Her return to Somalia gives her a sense of a purification of her soul: "it was as though she had become a virgin again" (203). Comparing Rhoda with Younis Tawfik's novel La Straniera (2001), Scego sees her tale in tragic terms: unlike Tawfik's protagonist who turns to prostitution for 'economic necessity', Scego's prostitute is “a student who doesn't do it out of need but, rather, because she wishes to annihilate herself [...]" (interview with Mauceri, El Ghibli 4). While the tragedy of Rhoda's plight overwhelms readers, there is a sense of hope generated by the experiences of the other characters in the narrative. Barni and Faduma, for example, find a new beginning by realizing their dream of opening a Somali clothes shop in Primavalle, a multiethnic suburb in the periphery of Rome.

In Rhoda, food is an important leitmotif. Gastronomic experiences feature prominently in the novel. Barni and Faduma discuss the pleasures of cooking and eating and prepare tea with great precision. Aisha's hedonistic enjoyment of a "mega-cone of chocolate-chip, coffee and coconut" ice-cream "with lots of soft, foamy cream on top" 
(Rhoda, 50) contrasts with Rhoda's asceticism: upon her arrival in Somalia, Rhoda is not suspected of having lived abroad as her gaunt body does not conform to "the prototype of the fat and opulent migrant" who has returned from the West (197).

A section entitled 'Faduma Aden's recipes', can be found at the back of the novel: the author includes Somali specialties such as sambusi (pastry filled with minced meat, onion and chilli), shai (cardamom and cinnamon spiced tea) and bagie (mixed legumes). The ingredients for Tè Helsinki (Helsinki Tea) - a version of shai with the addition of apple and peppermint - make readers aware that Finland is now home to large numbers of Somalis who have resettled there (215). The collection of recipes is reminiscent of Scego's biography of her mother, The Nomad Who Loved Alfred Hitchcock (Sinnos 2003), which also contains recipes for a number of Somali dishes.

Ali Farah's monologue Rapdipunt features in the Quaderni del ' 900 edition (2004) on postcolonial Italian literature, and was recited by the author as a piece of theatre as part of 'La città e il mondo' project, curated by Pierpaolo Palladino at the Vascello theatre, Rome, in March 2005 (Hoyet 2006:514). The short story is an illustration of the perspective of second generation migrants whose parents migrated from the Horn of Africa and is inspired by the events of the Flaminio Maphia, a group of young African Italians who are a regular feature in the local media due to their deviant behaviour. It is narrated by the only female member of the group who acts as their spokesperson. They stand at the entrance of one Rome's metro stations.

I'm sitting on our park bench that's always the same at Flaminio metro stop. There are so many people and I like to think about where people are headed but I also feel a little bit lonely, I don't know where to go. But it's the same for the guys, every day we think about our country. I don't know if I would want to go back there right now. 
Maybe in a little while, like Mauro says, to live for real.

(Ali Farah, Rapdipunt 2004:127)

The group visits a bar and their leader attempts to pay for a coffee: "How much you gonna take from us today? Mauro asks the barista, but he's short on patience. What do you mean gonna take from us? You owe me what you owe me. I'm not trying to rip you off! Here we go again [...]" (128). Mauro's appropriation of colloquial roman jargon in this context is not welcomed by the barista. His response is suggestive of the antagonism that Mauro and his companions encounter daily in their excursions around the city, heightening feelings of dislocation. When the group take the metro train together, their sense of collective alienation from the society they inhabit is evident. The narrator observes the behavior of the rest of the group outside the metro station.

People stare at us and I get agitated, because I know it only takes a second for them to start a fight, especially when the police are nearby, they provoke them and they have this idea that the police pick on us because we're black. Who knows how much truth there is in that. (129)

One morning Mauro is distracted from his troublemaking by a kind elderly man who takes him to the Botanic Gardens and talks about the boy's homeland; one assumes he speaks of Somalia.

The old man knew heaps about our country, maybe because he'd been there, and he said that there was a hero, some kind of head officer everyone listened to, and he had flabbergasted the English and the Italians during colonialism, because no one could keep up with him and he would leave poems around that made fun of everyone. This old guy knew so many things, and he persuaded Mauro to go to the Botanic Gardens with him. (130) 
They go to the gardens, a site of colonial memory, only to find that the incense plant native to Mauro's homeland is locked inside a greenhouse. Mauro's bemused reaction is met with the explanation that "you need a good climate like ours for it to survive" (130). His interest in the plant is indicative of a growing awareness of his roots that provides him with a sense of meaning that is otherwise absent in his existence in the city.

Mauro and the narrator decide to return to the greenhouse to take the "tiny ash green plant" that is "not that different to the others; yet to [them] for some reason it seem[s] magical" (130). Via the metaphor of the incense plant, Cristina Ali Farah renders visible Italy's latent colonial legacy: the pillaged plant, locked away by Italian authorities, can be seen to represent Somali culture which is then reclaimed by the Italo-Somali youths as their own.

Ali Farah and Scego's writing has not been limited to fiction. Scego tells the life story of her mother in La nomade che amava Alfred Hitchcock, and Ali Farah's collection of oral testimony shapes her narratives in powerful ways. One of Ali Farah's recent projects has been to interview migrant women in Rome and specifically Somali women. An outcome of this project is Ali Farah's short piece of creative non-fiction, L'Italia e $i$ Somali Dimenticati, featured in Migrantemente: Il popolo invisibile prende la parola, which is published by Editrice Missionaria Italiana, Bologna, 2005.

An example of the way in which the author gives expression to Somali women at the margins of Italian society, the title suggests an absence of awareness of Italy's links with Somalia. The protagonist of this narrative is a Somali refugee called Zahra, who was interviewed by the author. It is narrated in first person and appears as a form of testimony. The opening paragraph draws attention to the role of the interviewer in the articulation of the women's experiences.

Rome. We're sitting at a MacDonald's aluminium table and M.F. is unable to finish her story. Zahra, on the other hand, cannot wait. We've been here for over an hour and 
she wants to go to the call centre to telephone her mother in Somalia. Straight away she said that she needs to get this out of her system quickly so that the pain won't get the better of her. She recounts the events in a muted way without any emphasis, from start to finish without losing herself in memory. I don't dare interrupt with questions about details, which seem inappropriate and could hinder the free flow of memory. (Ali Farah 2005 L'Italia e $i$ somali dimenticati, 2005:47)

Zahra fled the civil war in Mogadishu, Somalia's capital, in 2001 to escape the armed conflicts that have become an everyday occurrence since the onset of civil war ten years earlier. She was in her third month of pregnancy at the time and describes giving birth unaided while on the road. She is approached by a passerby who offers her accommodation for six months in a village she believes to be on the border of Sudan and Ethiopia. The illness of her baby creates an urgent need to seek medical help in a larger city centre. Some Somali travelers in the village suggest she go with them on foot across the Sahara desert. During this expedition which Zahra describes as lasting a month, her now 18 month old daughter receives nothing but water. They eventually reach Sicily by boat.

In Sicily they took my daughter and I to hospital without saying a word. I didn't know whether they would have kept us there, or what was wrong with my daughter or whether they would have acknowledged me as an asylum seeker or anything. I stayed in Palermo for six months, sleeping on the threshold of the room where my daughter was a patient. She's paralyzed, poor thing. I don't know how aware she is, they say it's a result of all the difficulties I went through. Healthy babies aren't born in Mogadishu anymore. (49)

Today a year has gone by since I arrived and my status still hasn't been acknowledged. I have a foreigner's 
permit that is renewed every three months, I sleep on a seat next to my daughter at the Baby Jesus Hospital, I have no money and can't work... They tell me I can leave the child with them but after our journey together, I don't want to separate from her. (49-50)

Via this alarming narrative, Ali-Farah underscores the horrors Zahra experiences in Italy and in this way reminds readers of the need to consider post-migratory stressors - here a lack of laws to protect asylum seekers - in addition to pre-migratory ones.

Igiaba Scego's two short stories, 'Dismatria' and Salsicce (Sausages), placed at the beginning of the Pecore Nere (Black Sheep) collection, also emphasize the traumas experienced following migration that are associated with an absent sense of belonging in the host society. The two short stories considered here are worth analyzing in depth as they open a number of possible spaces for Somalis in Italy: 'Dismatria' focuses on Somali experiences of exile via a rehabilitation of historical memory while Salsicce critiques the antagonism towards immigration and cultural difference fostered by the Bossi-Fini legislation.

In 'Dismatria', the "title itself is a newly coined word indicating the loss of the mother country" (Curti 2007:68), unpacked suitcases in an all-female household without cupboards serve as a motif to reflect on Somalis living in exile, waiting to return to their homeland.

Mum was forever saying: 'If we keep all our things in suitcases, we won't need to pack in a rush when the time comes'. 'When the time comes' indicated some undefined future moment of triumphant return to mother Africa. So suitcases in hand, we would board the plane in preparation for the magnificent return, the extreme happiness, heat and tropical fruit. (Scego, 'Dismatria' 2005:10) 
Preferring to live in the present, the young narrator defines this fantasy of homecoming as a problematic 'infantile dream':

The dream had a name in our hearts, a secret name that we never uttered so as not to crumple it or worse.

So we waited...

And waited...

And waited..

But nothing happened. Nothing ever happened. We were perpetually waiting for an impossible return to our homeland. Our nightmare was called dismatria. Sometimes people would correct us, saying: 'In Italian you say expatriation, expatriate, you are, therefore, expats'. Sighing bitterly, we would shake our heads, and reply that we were in reality dismatriates. The umbilical cord tying us to our matria, Somalia, was definitively cut.

By living with unpacked suitcases, "a figurative expression of existential homelessness" (Papastergiadis, 1998:5), the women are, in effect, restricting the amount of room they take up in their host country. One might argue that their waiting status lies embodied in their suitcases, shut away from the Italian society in which they appear to reluctantly live. Lidia Curti sees in the suitcases "the symbol of a dream, the return to Somalia, and at the same time the reaffirmation of a life in which each phase of a nomadic life is represented by a different suitcase. They are the sign of impermanence as well as of the acceptance of nomadism as a way of life" (Curti 2007:69).

For Curti "the house is a way of confirming [a migrant's] existence in the elsewhere" (69). In their introduction to the collection of essays entitled Uprootings/Regroundings: Questions of Home and Migration, Sara Ahmed, Claudia Castaneda, Ann-Marie Fortier and Mimi Sheller draw attention to the 'laborious effort' involved in 'uprooting and regrounding homes', and seek to question how 'different bodies and communities inhabit and move across familial, national and diasporic 
locations" (Ahmed et al. 2003:1). Rather than "categoriz[ing] 'home' as a condition distinct from "migration", they propose asking "how uprootings and regroundings are enacted - affectively, materially and symbolically - in relation to one another" (2).

'Dismatria' reveals the interplay between uprooting and regrounding processes. Home and migration are renegotiated: on the one hand, it appears that the Somali women are content to live with unpacked suitcases as this represents their nomadic outlook. On the other, for the young narrator of the story who one assumes has lived most of her life in Italy, it is important to acquire cupboards and appear to have 'unpacked' in order to feel at home. Nikos Papastergiadis (1998:2) reflects that the home is "divided by symbolic boundaries" that "emerge from a matrix of identification and vary according to gender and age". As such, home is "more of a symbolic space than a physical place". The generational discrepancy between feelings of home in the narrator and her older Somali relatives affirms this idea.

'Dismatria' ends with the 'dismatriati' cathartically emptying out the contents of their suitcases in the living room: their history is literally 're-membered', and their home remade, in the array of random objects described below:

Hair clips, electric coloured tops, floral bracelets, books of poems, black and white photos... magazines, faded postcards and shoes, linen mantles, broken rosaries, creased paintbrushes, old VHS films, unused batteries, rag dolls, ruined incense burners, empty frames, damaged transistor radios, sewing scissors, unused floppy discs, yellowed notebooks...Our clothes, our secrets, our curses. ('Dismatria', 20)

Focusing on women's bodies and "their role in the regrounding of communities in the contexts of war, violence and displacement", Irene Gedalof observes that "homes are continually being remade by $[\ldots]$ 
women's bodies and agencies". Consequently, "women's work of reproducing domestic and broader cultural or national homes can take different shapes across successive generations" (Ahmed et al. 2003:12).

It is this very act of remembering, rather than passively waiting to return to their homeland, that paradoxically allows the women to begin to make themselves at home in their host country where they have a possible future. Opening one of her mother's suitcases, the protagonist discovers peculiarities such as "a packet of spaghetti, a plastic hunk of parmesan cheese [...] and a stone" ('Dismatria', 21). Her mother's comment that she "didn't want to forget Rome" reveals the degree to which Italy is experienced as another homeland for the Somalis in question.

Being at home in Italy is rendered problematic in Scego's Eks\&Tra (www.eksetra.net) award winning allography, which is a response to the introduction of the Bossi-Fini Law introduced in 2002, designed to toughen Italian migration laws. According to Papastergiadis (1998:188), allography "refers to those texts which are written from the borders or the unacknowledged positions within the West". Such texts emerge "from the crisis in defining a subject position both experientially and philosophically". In a conversation with Scego in 2007, she said that anger about issues surrounding immigration motivated her to write the story: "I was very angry - you know about those racist episodes that happen on the bus and with conductors on the metro? So I wrote Salsicce. People praised me and so I began to work more seriously on what was originally a bit of a mess" (interview with Igiaba Scego by Vivian Gerrand, Rome, $5^{\text {th }}$ November 2007).

Salsicce condemns the treatment of immigrants in Italy by the authorities - by whom they are reduced to numbers - and by the dominant forms of media in which they feature predominantly as criminals (Lonni 2003:18). The law stipulates that digital fingerprints will be taken from all the "extracomunitari who wish to renew their foreigner's permits" (Scego, Salsicce 2005:26). In this climate of 
dehumanization in which the figure of the immigrant has begun to acquire homo sacer status, the protagonist feels she must erase her cultural difference. To do this, she buys pork sausages for the first time with a view to consuming them, in spite of being a Sunni Muslim. She wonders whether by eating the sausages people will begin to see her as a 'true Italian'. The narrator's attempted assimilation is unsuccessful insofar as she vomits while on the verge of placing the sausage in her mouth (31-32).

Salsicce is narrated by someone who has grown up with the awareness to move fluently between different cultures. Yet this ability goes unrecognized in the author's homeland, Italy. Indeed, the introduction of the discriminatory Bossi-Fini legislation has the writer contemplating her Somali cultural heritage and the ways in which it informs her everyday existence. Focusing on her identity, the narrator asks herself whether she is more Italian or more Somali: "More Somali? More Italian? Perhaps $3 / 4$ Somali and 1/4 Italian? I don't know! I have never needed to 'fraction' myself before now". In an officious tone that resembles a police report, the author lists various cultural aspects of her life that are categorized as either Italian or Somali.

Let's see. I feel Somali when: 1) I drink tea spiced with cardamom, cinnamon and cloves; 2 ) I recite the five daily prayers to Mecca; 3) I wear a dirah; 4) I perfume the house with incense or unsi [...] 12) I weep for my warravaged country [...] I feel Italian when: 1) I eat a sweet breakfast; 2) I visit art exhibitions, museums and monuments; 3) I talk about sex, men and depression with friends; 4) I watch films starring Alberto Sordi, Nino Manfredi, Vittorio Gassman, Marcello Mastroianni, Monica Vitti, Totò, Anna Magnani, Giancarlo Giannini, Ugo Tognazzi, Roberto Benigni, Massimo Troisi [...] 12) I sing Mina's Un anno d'amore in the shower. (28)

The carefully calculated catalogue suggests the artifice inherent in such divisions between cultural practices and works to critique the 
Bossi-Fini Law's reduction of human subjects to a series of digits and allegiances. Moreover, Scego affirms that her cultural influences do not cancel each other, challenging the assumption that one's cultural heritage must be discarded in order to adopt other cultural paradigms. In summary, the texts discussed subvert preconceived notions of Italian identity in multiple ways. By drawing attention to the colonial and historical ties between Italy and Somalia and representing the predicament Somalis dispersed in the world, including the realities of living in Italy as a non-citizen, Ali Farah and Scego affirm the need for a new politics of inclusion. The literature produced by Cristina Ali Farah and Igiaba Scego opens spaces in which readers witness the dynamic interaction between cultures, histories and languages rather than perceiving them as exclusive entities. What it is to be Italian is thus revealed as complex and capable of accommodating difference: perhaps in movement towards an official model of citizenship offered to Somalis.

(University of Melbourne)

\section{Bibliography}

Ahad, A. M.

Ahad, A.M. \&

Gerrand, V.

Ahmed et al.

Ali Farah, C.
2006

2004

2003

2005
Corno d'Africa. L'ex-impero italiano. In: Gnisci (ed.) Nuovo Planetario Italiano. Roma: Città Aperta.

Italian Cultural Influences in Somalia. A Reciprocity? Quaderni del 900: La Letteratura Postcoloniale Italiana, 4: 13-24.

Uprootings/Regroundings: Questions of Home and Migration. Oxford: Berg.

L'Italia e $i$ somali dimenticati. In: Annecchiarico,

(ed.), 
Migrantemente: Il popolo invisibile prende la parola. Bologna: Editrice Missionaria Italiana:47-50.

Ali Farah, C.

Ali Farah, U.C.

Ben-Ghiat, R. \& Fuller, M.

Bogue, R.

Capitani, F. \& Coen, E.

Curti, L.

De Donno, F. \&

Srivastava, N.

Del Boca, A.

Einaudi, L.

Farah, N

Gilroy, P.

Giustiniani, C.
Madre Piccola. Milano: Frassinelli.

Rapdipunt. Quaderni del '900. 4:127130.

Italian Colonialism. New York: Palgrave Macmillan.

Deleuze on Literature. London: Routledge.

'E l'Italia gira pagina con gli scrittori venuti dall'Africa.' Il Venerdi 7 January:43.

Female literature of migration in Italy. Feminist Review 87 (1):60-75.

Colonial and Postcolonial Italy. Interventions: International Journal of Postcolonial Studies, 8 (3):371-379. November.

Italiani, brava gente? Milano: Neri Pozza.

Le politiche dell'immigrazione in Italia dall'Unità a oggi. Bari: Laterza.

Yesterday, Tomorrow. Voices From the Somali Diaspora. New York \& London: Cassell.

Between Camps. Great Britain: Routledge.

Fratellastri d'Italia. Bari: Laterza. 
Gnisci, A. (ed)

Gnisci, A. (ed.)

Hanna, M.

Hoyet, M.

Lo, J.

Lonni, A.

Mezzadra, S.

Papastergiadis, N.

Ponzanesi, S.

Portelli, A.
Allattati dalla Lupa. Scritture Migranti. Roma: Sinnos.

Nuovo Planetario Italiano. Roma: Città Aperta.

'Non siamo gli unici polemici': Intersecting Difference and the Multiplicity of Identity in Igiaba Scego's Salsicce. Quaderni del 900: La Letteratura Postcoloniale Italiana, 4:67-76.

Voci afroitaliane in scena per una prima ricognizione. In: Gnisci, A. (ed.), Nuovo Planetario Italiano.

Beyond Happy Hybridity: Performing Asian-Australian Identities. In: Ien Ang et al., Alter Asians: Asian Australian Identities in Art, Media and Popular Culture. Sydney: Pluto.

Immigrati. Milano: Mondadori.

Diritto di fuga. Migrazioni, cittadinanza, globalizzazione. Verona: ombre corte.

Dialogues in the Diasporas. London: Rivers Oram Press.

Il postcolonialismo italiano. Figlie dell'impero e letteratura meticcia. Quaderni del 900: La Letteratura Postcoloniale Italiana 4:25-34.

Fingertips Stained with Ink. Notes on New 'Migrant Writing' in Italy. Interventions. International Journal of 
Postcolonial Studies, 8 (3):472-483.

November.

Pugliese, J.

Scego, I.

Scego, I.

Scego, I.

Siggers Manson, C.

Tawfik, Y.

Triulzi, A.
2007

2006

2004

2006

2004

2001

2006
Australian Humanities Review, 42:11, August-September.

'Dismatria'. In: Capitani, F. \& Coen, E. (eds.), Pecore Nere. Bari: Laterza.

Rhoda. Roma: Sinnos.

Salsicce. In: Capitani, F. \& Coen, E. (eds.), Pecore Nere. Bari: Laterza.

Sausages and Cannons. Quaderni del '900: La Letteratura Postcoloniale Italiana, 4:77-86.

La Straniera. Milano: Bompiani.

Displacing the Colonial Event. Interventions: International Journal of Postcolonial Studies, 8 (3):430-443. November.

\section{Interviews:}

Interview with Cristina Ali Farah by Vivian Gerrand. Rome, 22 July 2005.

Interview with Igiaba Scego by Vivian Gerrand, Rome, 5 November 2007.

Interview with Igiaba Scego by Maria Cristina Mauceri, El-Ghibli 4. 